\title{
Recurrence of the eelgrass wasting disease at the border of New Hampshire and Maine, USA*
}

\author{
F. T. Short ${ }^{1}$, A. C. Mathieson ${ }^{1,2}$ \& J. I. Nelson ${ }^{3}$ \\ 'Jackson Estuarine Laboratory, University of New Hampshire RFD 2, Adams Point, Durham, New Hampshire 03824, USA \\ ${ }^{2}$ Department of Botany and Plant Pathology, University of New Hampshire, Durham, New Hamsphire 03824, USA \\ ${ }^{3}$ New Hampshire Fish and Game Department, Fisheries Division, Bridge Street, Concord, New Hampshire 03301, USA
}

\begin{abstract}
Eelgrass Zostera marina L. populations in the Great Bay Estuary, on the New Hampshire-Maine border, decreased dramatically between 1981 and 1984. The immediate cause of this decline was not pollution as found recently in other estuaries, but an infection of healthy leaf tissue by a microorganism. The slime mold Labyrinthula, associated with the 1930 's eelgrass wasting disease that devasted populations on both sides of the North Atlantic, was isolated from eelgrass tissue, as were other possibly infectious microorganisms. In addition to the decline of eelgrass in the estuary, we have documented the sequence of infection and die-back in mesocosm and laboratory eelgrass cultures that resulted in conditions analogous to those observed in the estuary.
\end{abstract}

The disappearance of eelgrass Zostera marina L. from coastal waters of Europe and North America in the early 1930's was a major natural catastrophe (Milne \& Milne 1951, Rasmussen 1977). Researchers evaluating the causes of this dramatic decline, termed the 'wasting disease', proposed 2 causal agents: an infectious slime mold, Labyrinthula (Cotton 1933, Petersen 1933, Renn 1934, Cottam \& Addy 1947); and environmental stress from abnormally warm temperatures increasing the plant's susceptibility to ever-present microorganisms (Rasmussen 1977). Whatever the cause, the environmental impact of the wasting disease was extensive, encompassing alterations in current patterns and sediment distribution, disruption of coastal food chains and fisheries, and losses of major populations of migratory waterfowl (Stevens 1936. Tutin 1938, Rasmussen 1977. Thayer et al. 1984).

More recent eelgrass declines have been blamed on environmental pollution and human impact in coastal areas (Orth \& Moore 1983). However, like the decline of the 1930's, there is controversy about the actual

- Scientific Contribution No. 188 from the Jackson Estuarine Laboratory and No. 1313 from the New Hampshire Agricultural Experiment Station cause of these recent events (Jones \& Tippie 1983, Kemp et al. 1983, Nienhuis 1983). The loss of eelgrass and other submerged aquatic plants in the Chesapeake Bay has been variously attributed to eutrophication, herbicides from runoff, and increased turbidity from development (Jones \& Tippie 1983, Kemp et al. 1983). A seagrass decline in southwestern Australia was linked to industrial expansion and alteration of harbor circulation (Cambridge \& McComb 1984). An analysis of eelgrass decline within the tidally restricted Grevelingen Lake in Holland suggested that increased nutrient loading produced toxic conditions in the sediments (Nienhuis 1983).

A major decline of eelgrass populations has now been detected in the Great Bay Estuary on the New Hampshire-Maine border (Fig. 1), and the virtual disappearance of eelgrass from the outer estuary has been linked not to pollution but to a disease. Monitoring of the Piscataqua River and Little Bay where abundant eelgrass grew in 1981 revealed no viable eelgrass beds in 1984. Either dead matted rhizomes were found with only residual reproductive stems, or scattered shoots were observed where large beds formerly thrived. The eelgrass tissue that remained had black patches on the leaves. The furthest up-estuary extent of the decline was Furber Straits. This is the site of the Jackson Estuarine Laboratory (JEL) where the decline sequence was observed in mesocosm eelgrass cultures during 1984. The eelgrass sampling stations for both 1981 and 1984 are shown on the lower map in Fig. 1. Stn 1 and 2 are in the Piscataqua River, Stn 3 to 5 in Little Bay and Stn 6 and 7 in Great Bay. Eelgrass leaf abundance at these stations is reported for the seasonal peak biomass in July. Ten replicate samples for 1980 , 1981 and 1984 were collected from $1 / 9 \mathrm{~m}^{2}$ areas using SCUBA. The 1980-81 biomass pattern showing 

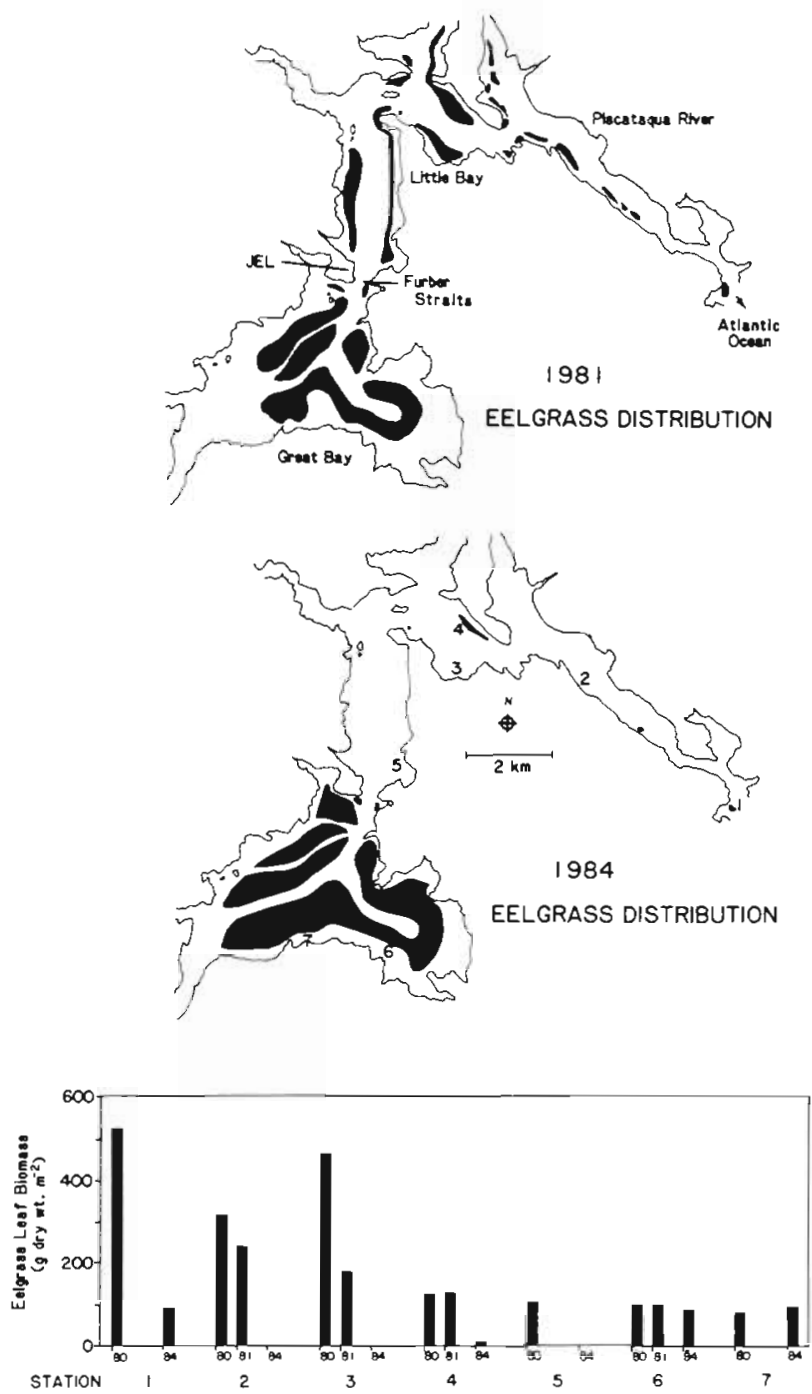

Fig. 1. Eelgrass distribution and biomass in the Great Bay Estuary, New Hampshire-Maine. Based on a 1981 survey of the estuary (Nelson 1981) and on aerial photographs and ground truth sampling in 1984. The marked decline in eelgrass throughout the lower estuary (Piscataqua River and Little Bay) contrasts with the increased distribution in the upper estuary (Great Bay)

decreased biomass up-estuary is reversed in 1984 since eelgrass disappeared from much of the Piscataqua River and Little Bay (Stn 2, 3, 4, 5). No examples of half-dead and heavily epiphytized shoots were observed, such as were noted during the recent Chesapeake Bay eelgrass decline (Orth \& Moore 1983). That is, none of the beds showed symptoms of die-back due to turbidity, reduced light levels, or eutrophication. Rather, they resembled the symptoms described in the 1930's.

The disappearance of eelgrass from the Great Bay Estuary has not been geographically uniform. The line demarcating the present die-off of eelgrass popula- tions, Furber Straits, is a narrow channel with fast currents separating Little Bay from Great Bay proper (Fig. 1). The waters in Great Bay, up-estuary from the straits, are well mixed (Brown \& Arrelano 1979, Swift \& Brown 1983) and have consistently lower salinities and higher summer temperatures (Fig. 2) than down-estuary in Little Bay and the Piscataqua River. In the

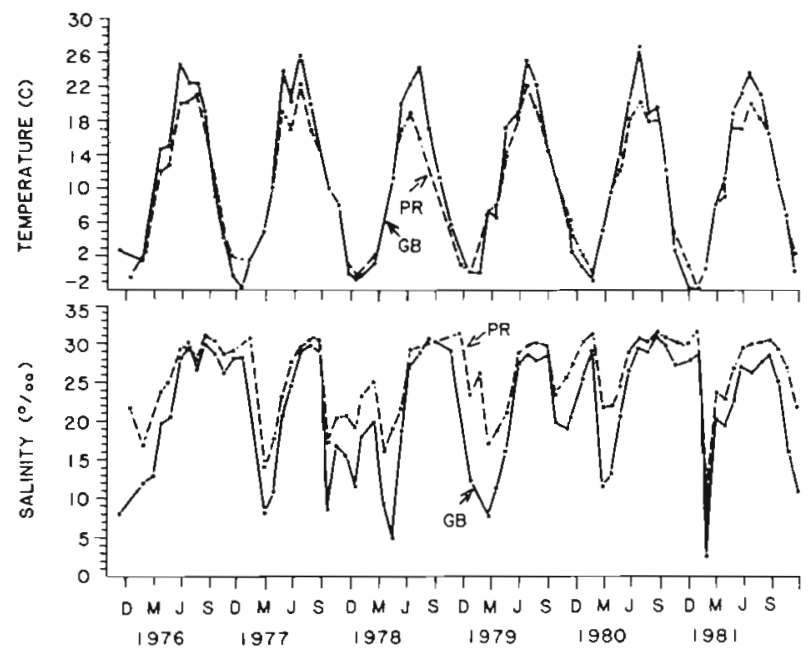

Fig. 2. Temperature and salinity records for 2 stations in the Great Bay Estuary for 1976-1981 (C. Emerich Penniman, unpubl. data). Data for Great Bay (GB) is from a monitoring station situated in the central channel $1 \mathrm{~km}$ into the bay. Data for the Piscataqua River (PR) is from the central channel adjacent to Stn 2. Temperatures were substantially higher during summer in Great Bay than down-estuary, while salinity was consistently lower than in the Piscataqua River. Temperature and salinity data collected at JEL in 1984 show similar ranges

1930 's, eelgrass beds in low-saline estuarine waters survived the wasting disease to repopulate the coasts of Europe and North America (Stevens 1939, Cottam 1941). Although the highly saline Piscataqua River and Little Bay have experienced a die-back, Great Bay proper has experienced an increase in eelgrass distribution from 1981-84 (Fig. 1). Nutrient levels and turbidity conditions were generally similar throughout Great Bay, Little Bay, and the Piscataqua River (Nelson 1981, Loder et al. 1983).

An analysis of circumstantial evidence on the disappearance of eelgrass in the Great Bay Estuary revealed neither the progression nor the cause of this decline. However, the symptomatic sequence of die-back was documented during a mesocosm culture study of eelgrass at the Jackson Estuarine Laboratory (Short 1985). The die-back within the mesocosm resulted in conditions analogous to those observed in the estuary. Beginning in September 1984, small black patches appeared on the leaves of plants in the field and of healthy cultured plants growing in 3 tanks. Between 
September 17 and 27 large numbers of leaves detached and floated to the surface. The tank most severely affected lost $90 \mathrm{~g}$ dry weight $\mathrm{m}^{-2}$ of leaf material in this $10 \mathrm{~d}$ period, compared to $5 \mathrm{~g}$ dry weight $\mathrm{m}^{-2}$ during the previous $10 \mathrm{~d}$. By October 3, the leaves in this tank had turned completely black and sunk to the bottom. During the subsequent winter, the plants did not defoliate in the normal fashion; rather the blackened leaves remained attached to the rhizomes and lay on the mud surface. Only a few reproductive stems remained floating in the water column. The plants stopped photosynthesizing; their lacunal spaces were deflated. The eelgrass decline did not occur in all tanks despite the same environmental conditions. Thus, there was no clear naturally occurring environmental cause for the decline. The plants in 2 tanks recovered and continued to grow. The variability between tanks of eelgrass decline suggested a disease mechanism.

Two causes for the decline remained possible: either coastal pollution (Orth \& Moore 1983) or an infectious disease such as that described in the 1930's (Renn 1936, Rasmussen 1977). The 1981-84 decline originated in the lower reaches of the Great Bay Estuary. Thus, eutrophication from one or more of the tidal tributaries was not the likely agent. The possibility of industrial and agricultural pollution entering the Piscataqua River was considered. No increased concentration of organic pollutants has been documented, and there is no evidence of substantial herbicides in the estuary (1985 Shellfish Survey, J. I. Nelson, pers. obs.).

The other possible cause of the decline is a microbial epidemic. Laboratory experiments with eelgrass in culture flasks of $30 \%$ salinity showed $100 \%$ infection and $75 \%$ death of healthy eelgrass plants after $3 \mathrm{wk}$ when exposed to leaf tissue from the tank showing

Table 1. Zostera marina. Growth of eelgrass in a laboratory culture flask experiment. Shoots were incubated in $30 \%$ artificial seawater with and without blackened eelgrass tissue and in $10 \%$ artificial seawater with blackened tissue. Mean and standard deviation, $\mathrm{N}=4$

\begin{tabular}{|lccc|}
\hline & $\begin{array}{c}\text { Salinity } \\
30 \% \\
\text { Control }\end{array}$ & $\begin{array}{c}\text { Salinity } \\
30 \% \\
\text { With black } \\
\text { tissue }\end{array}$ & $\begin{array}{c}\text { Salinity } \\
10 \% \text { With black } \\
\text { tissue }\end{array}$ \\
\hline $\begin{array}{l}\text { Leaf area }\left(\mathrm{cm}^{2}\right) \\
\text { Initial } \\
\text { Leaf area }\left(\mathrm{cm}^{2}\right)\end{array}$ & $4.3 \pm 1.1$ & $3.6 \pm 0.8$ & $5.6 \pm 3.0$ \\
$\begin{array}{l}\text { After } 3 \text { wks } \\
\text { Net growth } \\
\left(\mathrm{cm}^{2} \text { shoot }\right.\end{array}$ & $9.3 \pm 3.5$ & $\left.4.9 \pm 0 . \mathrm{d}^{-1}\right)$ & $10.7 \pm 6.1$ \\
$\cdot 3$ out of 4 shoots died $^{-3}$ & $0.27 \pm 0.20$ & $0.06 \pm 0.02 *$ & $0.28 \pm 0.18$ \\
\hline
\end{tabular}

evidence of dieback (Table 1). Eelgrass in control flasks remained healthy and grew substantially throughout the experimental period. Additionally, healthy eelgrass in a second treatment of $10 \%$ salinity grew despite the presence of black tissue. Detailed examination of the eelgrass tissue from these experiments demonstrated the presence of Labyrinthula and other microorganisms. These results support the hypothesis of a wasting disease of microbial origin. However, they leave open the question of whether Labyrinthula or another organism is the causal agent. The similarities of the culture plant loss to the wasting disease of the 1930's and to the recent Great Bay Estuary eelgrass decline suggest that a microorganism was the cause of the large-scale losses of eelgrass.

The question arises at it did after the wasting disease of the 1930's: what might increase eelgrass susceptibility to ubiquitous microorganisms? Studies of the 1930's epidemic have correlated abnormally high temperatures with the wasting disease (Rasmussen 1977). Our mesocosm and laboratory culture studies under isothermal conditions indicate that temperature alone is not the primary predisposing factor. We conclude that either the microorganism in question is nonubiquitous or eelgrass susceptibility to an infectious microorganism can change.

Acknowledgements. We thank Catherine Short and Drs. Mark Hines, Galen Jones and Linn Bogle for their comments on the manuscript. This research was funded by the University of New Hampshire and New Hampshire Department of Fish and Game.

\section{LITERATURE CITED}

Brown, W. S., Arrelano, E. (1979). The application of a segmented tidal mixing model to the Great Bay Estuary, N. H. Univ. New Hampshire Sea Grant Rept., UNH-SG-162

Cambridge, M. L., McComb, A. J. (1984). The loss of seagrasses in Cockburn Sound, Western Australia. I. The time course and magnitude of seagrass decline in relation to industrial development. Aquat. Bot. 20: 229-243

Cottam, C. (1941). The eelgrass situation, fall 1940. Plant Dis. Reptr. 25: 46-52

Cottam, C., Addy, C. E. (1947). Present eelgrass condition and problems on the Atlantic coast of North America. Proc. 12th North Am. Wildlife Conf., San Antonio, Texas, p. $387-398$

Cotton, A. D. (1933). Disappearance of Zostera marina. Nature, Lond. 132: 277

Jones, G. A., Tippie, V. K. (1983). Chesapeake Bay program: findings and recommendations. US Environmental Protection Agency, Philadelphia

Kemp, W. M., Twilley, R. R., Stevenson, J. C., Boynton, W. R., Means, J. C. (1983). The decline of submerged vascular plants in the upper Chesapeake Bay: Summary of results concerning possible causes. Mar. Tech. Soc. J. 17: 78-89

Loder, T. C., Love, J. A., Penniman, C. E., Neefus, C. D. (1983). Long-term environmental trends in nutrient and hydrographic data from the Great Bay Estuarine System, 
New Hampshire-Maine. Univ. New Hamsphire Marine Program, UNH-MP-D/TR-SG-83-6

Milne L. J., Milne, M. J. (1951). The eelgrass catastrophe. Scient. Am. 184: 52-55

Nelson, J. I. (1981). Inventory of natural resources of Great Bay Estuarine System. New Hampshire Fish and Game Dept., Concord

Nienhuis, P. H. (1983). Temporal and spatial patterns of eelgrass (Zostera marina L.) in a former estuary in The Netherlands, dominated by human activities. Mar. Tech. Soc. J. 17: 69-77

Orth, R. J., Moore, K. A. (1983). Chesapeake Bay: An unprecedented decline in submerged aquatic vegetation. Science 222: 51-52

Petersen, H. E. (1933). Wasting disease of eelgrass (Zostera marina). Nature, Lond. 132: 1004

Rasmussen, E. (1977). The wasting disease of eelgrass (Zostera marina) and its effects on environmental factors and fauna. In: McRoy, C. P., Helfferich, C. (ed.) Seagrass ecosystems: a scientific perspective. Marcel Dekker, New York, p. 1-52
Renn, C. E. (1934). Wasting disease of Zostera in American waters. Nature, Lond. 134: 416

Renn, C. E. (1936). Wasting disease of Zostera marina L. A phytological investigation of the diseased plant. Biol. Bull. mar. biol. Lab., Woods Hole 70: 148-158

Short, F. T (1985). A method for the culture of tropical seagrasses. Aquat. Bot. 22: 187-193

Stevens, N. E. (1936). Environmental conditions and the wasting disease of eelgrass. Science 84: 87-89

Stevens, N. E. (1939). Environmental factors and the wasting disease of eelgrass. Rhodora 41: 260-262

Swift, M. R., Brown, W. S. (1983). Distribution of bottom stress and tidal energy dissipation in a well-mixed estuary. Estuar. coast. Shelf Sci. 17: 297-317

Thayer, G. W., Kenworthy, W. J., Fonseca, M. S. (1984). The ecology of eelgrass meadows of the Atlantic coast: a community profile. U.S. Fish Wildl. Serv. FWS/OBS-84/02

Tutin, T.G. (1938). The autecology of Zostera marina in relation to its wasting disease. New Phytol. 37: 50-71

Accepted for printing on November 18, 1985 